\title{
Assessment of Tuberose (Polianthes tuberosa L.) Varieties for Growth and Flower Yield
}

\author{
V. Sivakumar ${ }^{1 *}$, K. Kumanan ${ }^{2}$, A. Kamaraj ${ }^{3}$, R. Balakumbahan ${ }^{4}$ and V. Alex Albert ${ }^{5}$ \\ ${ }^{1}$ Coconut Research Station, Aliyarnagar, Coimbatore - 642 101, India \\ ${ }^{2}$ Horticultural College and Research Institute for Women, Tiruchirapalli - 620 027, India \\ ${ }^{3}$ Agricultural College and Research Institute, Eachangkottai, Thanjavur -614 902, India \\ ${ }^{4}$ Horticultural College and Research Institute, Periyakulam, Theni- 625 604, India \\ ${ }^{5}$ ICAR-Krishi Vigyan Kendra, Sirugamani - 639 115, Tiruchirappalli District, India
}

*Corresponding author

\section{A B S T R A C T}

A field investigation on suitability assessment of tuberose varieties for growth and flower yield characters was carried out at five different farmers' fields at Valangaiman block of

\section{Keywords}

Tuberose

(Polianthes

tuberosa L.)

Varieties

\section{Article Info}

Accepted:

10 July 2020

Available Online:

10 August 2020
Thiruvarur district during the year 2012-14. The trial was laid out in randomized block design (RBD) with three varieties (Prajwal, Phule Rajini and local check) with five replications. The observation on growth, flower yield and cost benefit ratio were recorded and analysed statistically. The experimental results revealed that the highest plant height $(63.8 \mathrm{~cm})$, number leaves per plant $(45.3)$, plant coverage $\left(612.4 \mathrm{~cm}^{2}\right)$, spike length $(87.3)$, rachis length $(40.2 \mathrm{~cm})$, florets per spike (55.6), floret length $(5.6 \mathrm{~cm})$, floret diameter $(4.2 \mathrm{~cm})$, weight of floret $(1.5 \mathrm{~g})$, number spikes per plant $(2.9)$, number of bulbs per plant (17.2), bulb weight $(12.3 \mathrm{~g})$, bulb diameter $(1.9 \mathrm{~cm})$ and yield per hectare $(15.2 \mathrm{t} / \mathrm{ha})$ ) were recorded in Prajwal followed Phule Rajini. In the studied area Prajwal took 92 days for first flowering against 123.6 days i local check. Regarding the economics of cultivation, the variety Prajwal recorded higher gross income (Rs.3,04,000/ha), net income (Rs.1,7,3000/ha) and benefit cost ration (3.5). Based on the performance it is concluded that, prajwal variety is ideally suitable for commercial cultivation under Thiruvarur condition.

\section{Introduction}

Tuberose (Polianthes tuberosa L.) is one of the commercially significant loose and cut flowers in India. Two group of tuberose flowers viz., single and double cultivars are available for cultivation. The waxy white flowering spikes of both single as well as double types of tuberose infuse the environment with sweet perfume and because of the longer table quality (Sadhu and Bose, 1973, Benschop et al., 1993). Tuberose is cultivated on a large scale in Tamil Nadu, Karnataka, West Bengal and Maharashtra. Valuable natural aromatic oil is extracted from the flowers fetches high cost in perfume industry. It is widely grown as a specimen for display as cut flower too. Its essential oil is 
exported at an attractive price to France, Italy and other countries, as long as there is no synthetic flavour to replace its fragrance. There are only a few varieties and hybrids of tuberose under cultivation. As the commercial cultivation of tuberose is gaining importance, identification and assessment of high yielding varieties is necessary for particular region to obtain sustainable and economic profit by the farmers. Since the performances of crops may vary from region to region (Kamble et al., 2004) it is important to study the variation and performance of varieties in a new location to enhance the production efficiency. Hence, the present field study was undertaken to find out the suitable tuberose varieties for Thiruvarur district of Tamil Nadu.

\section{Materials and Methods}

The present study was carried out at five different farmers' fields at Valangaiman block of Thiruvarur district during the year 2012-14. The location is situated at $10^{\circ} 77^{\prime \prime} \mathrm{N}$ latitude, $79^{\circ} 37^{\prime \prime}$ E longitude and $17 \mathrm{~m}$ above mean sea level. The investigational material includes two improved varieties of tuberose varieties viz., Prajwal, Phule Rajani along with local check. The experiment was laid out in a randomized block design (RBD) with five replications.

The experiment plot was brought to a fine tilt with four deep ploughings. Weeds, stubbles, roots etc., were removed and farm yard manure at the rate of $25 \mathrm{t} \mathrm{ha}^{-1}$ was applied at the time of the last ploughing. After levelling, raised beds of $1 \mathrm{~m}$ width and $1 \mathrm{~m}$ length were formed and medium sized bulbs $(3.0-3.5 \mathrm{~cm}$ diameter) of about 25 grams were planted at a spacing of $45 \mathrm{~m} \times 20 \mathrm{~m}$ which accommodates 11 plants per square meter. Standard cultural practices as recommended by the Tamil Nadu Agricultural University were followed throughout the experimentation. The data were recorded in ten plants tagged from each replication for growth, flower and yield characters. The collected data were analysed for statistical significance as per the methods of Panse and Sukhatme, 1985.

\section{Results and Discussion}

All the growth parameters recorded showed significant variation between the varieties evaluated. The results revealed that, improved varieties of tuberose performed better than local check with respect to all plant growth and yield characters. Among the improved varieties, significant highest plant height $(63.8 \mathrm{~cm})$, number leaves per plant (45.3), plant coverage $\left(612.4 \mathrm{~cm}^{2}\right)$, spike length (87.3), rachis length $(40.2 \mathrm{~cm})$, florets per spike (55.6), floret length $(5.6 \mathrm{~cm})$, floret diameter $(4.2 \mathrm{~cm})$, weight of floret $(1.5 \mathrm{~g})$ and number of spikelet's per plant (2.9) were reordered in Prajwal variety followed by Phule Rajani. Similar results were also reported by Gudi (2006) and Vijayalaxmi et a., (2010). Varietal dissimilarity in performance among the tuberose varieties evaluated was also observed by Ramachandrudu et al., (2009) and Prashanta et al., (2016). Different varieties performed better for different floral parameters which might be due to the inherent capacity of the particular genotype as well as the prevailing climatic conditions during the growing period (Urfi Fatmi and Devi Singh, 2020). Earliness in flowering is an important character, which helps farmers to fetch early market with increased price. Accordingly, the variety Prajwal took only 92.6 days to for the commencement flowering against 101.5 days and 123.6 days in Phule Rajani and local check respectively.

Elite and vigorous propagating material is the prerequisite for commercial production of any crop. Bulb quantity, superiority and yield provide added farm revenue in addition to the sale of flower. 
Table.1 Growth and flower characters of tuberose varieties at Thiruvarur district

\begin{tabular}{|c|c|c|c|c|c|c|c|c|c|c|c|}
\hline Variety & $\begin{array}{c}\text { Plant } \\
\text { height } \\
(\mathrm{cm})\end{array}$ & $\begin{array}{c}\text { Number } \\
\text { of } \\
\text { leaves/ } \\
\text { plant }\end{array}$ & $\begin{array}{c}\text { Plant } \\
\text { coverage } \\
\left(\mathrm{cm}^{2}\right)\end{array}$ & $\begin{array}{l}\text { Days to } \\
\text { first } \\
\text { flowering }\end{array}$ & $\begin{array}{c}\text { Spike } \\
\text { length } \\
\text { (cm) }\end{array}$ & $\begin{array}{c}\text { Rachis } \\
\text { length } \\
\text { (cm) }\end{array}$ & $\begin{array}{l}\text { Florets } \\
\text { /spike }\end{array}$ & $\begin{array}{l}\text { Floret } \\
\text { length } \\
(\mathrm{cm})\end{array}$ & $\begin{array}{l}\text { Floret } \\
\text { diameter } \\
(\mathrm{cm})\end{array}$ & $\begin{array}{l}\text { Weight } \\
\text { of } \\
\text { floret } \\
\text { (g) }\end{array}$ & $\begin{array}{c}\text { No. of } \\
\text { Spikes } \\
\text { per } \\
\text { plant }\end{array}$ \\
\hline Prajwal & 63.8 & 45.3 & 612.4 & 92.6 & 87.3 & 40.2 & 55.6 & 5.6 & 4.2 & 1.5 & 2.9 \\
\hline Phule Rajini & 60.2 & 42.8 & 532.3 & 101.5 & 75.1 & 36.9 & 50.4 & 5.2 & 3.8 & 1.3 & 2.3 \\
\hline local check & 52.3 & 31.6 & 326.6 & 123.6 & 62.8 & 32.8 & 38.8 & 4.3 & 3.2 & 0.9 & 1.9 \\
\hline SEd & 1.1 & 0.7 & 8.9 & 2.1 & 1.4 & 0.6 & 1.1 & 0.1 & 0.1 & 0.03 & 0.04 \\
\hline $\mathrm{CD}(\mathrm{P}=0.05 \%)$ & 3.1 & 2.0 & 18.2 & 5.2 & 3.2 & 1.3 & 2.4 & 0.2 & 0.2 & 0.06 & 0.12 \\
\hline
\end{tabular}

Table.2 Bulb characters and yield of tuberose varieties at Thiruvarur district

\begin{tabular}{|l|c|c|c|c|}
\hline \multicolumn{1}{|c|}{ Variety } & $\begin{array}{c}\text { No. of bulbs } \\
\text { / plant }\end{array}$ & $\begin{array}{c}\text { Bulb weight } \\
(\mathbf{g})\end{array}$ & $\begin{array}{c}\text { Bulb diameter } \\
(\mathbf{c m})\end{array}$ & $\begin{array}{c}\text { Yield per hectare } \\
(\mathbf{q} / \mathbf{h a})\end{array}$ \\
\hline Prajwal & 17.2 & 12.3 & 1.9 & 15.2 \\
\hline Phule Rajini & 14.3 & 9.5 & 1.6 & 13.6 \\
\hline local check & 12.8 & 7.6 & 1.2 & 10.6 \\
\hline SEd & 0.3 & 0.2 & 0.03 & 0.3 \\
\hline $\mathrm{CD}(\mathrm{P}=0.05 \%)$ & 0.7 & 0.5 & 0.07 & 0.6 \\
\hline
\end{tabular}

Table.3 Economics of tuberose varieties at Thiruvarur district

\begin{tabular}{|l|c|c|c|c|c|}
\hline \multicolumn{1}{|c|}{ Variety } & $\begin{array}{c}\text { Yield per ha } \\
\text { (t/ha) }\end{array}$ & $\begin{array}{c}\text { Gross Cost } \\
\text { (Rs.) }\end{array}$ & $\begin{array}{c}\text { Gross } \\
\text { Income (Rs.) }\end{array}$ & $\begin{array}{c}\text { Net Returns } \\
\text { (Rs.) }\end{array}$ & B:C ratio \\
\hline Prajwal & 15.2 & $85000 /$ ha & $304000 /$ ha & $173000 /$ ha & 3.5 \\
\hline Phule Rajini & 13.6 & $85000 /$ ha & $272000 /$ ha & $146000 /$ ha & 3.2 \\
\hline local check & 10.6 & $75000 /$ ha & $190800 /$ ha & $111000 /$ ha & 2.5 \\
\hline
\end{tabular}


The bulb size plays an essential role on the growth and flowering of tuberose and it manipulate the sprouting of bulb (Sadhu and Das, 1978; Pathak et al., 1980). Bulb volume is also having positive correlation with early flowering and higher yield of flower spikes (Yadav et al., 1985). In the present study significant differences in bulb characters among the varieties were noticed. The maximum number of bulb per plant (17.2), bulb weight $(12.3 \mathrm{~g})$, bulb diameter $(1.9 \mathrm{~cm})$ and flower yield (15.2 t/ha) were registered by the variety Prajwal flowed by Phule Rajini. The lowest number of bulb per plant (12.8), bulb weight $(7.6 \mathrm{~g})$, bulb diameter $(1.2 \mathrm{~cm})$ and flower yield (10.6 t/ha) were recorded by the local check. The favourable bulb parameters by Prajwal will be utilized for production elite, healthy and vigorous planting material for next season. Higher reserve food in bigger bulbs and translocation of reserved energy during plant growth phase ultimately helps in better establishment and growth. With regard to spike length and flower yield, the variety Prajwal showed better performance than other tested types. This might be due to the wide adoptable capacity of the particular variety to diverse climatic conditions (Bindiya et al., 2018)

\section{Economics}

Better adoptability, yielding capability and marketability in tuberose plant are the direct signs to fetch better returns. Though the gross cost of cultivation of local type was recorded the lowest due its reduced cost of planting materials the improved varieties showed better performance in case of yield characters thereby the net returns were higher than in local types. Among the tuberose varieties, market preference was high for var. Prajwal and fetched elevated prices. Prajwal recorded the highest net profit of Rs.1,73,000/ha with the benefit to cost ratio of 3.5 followed by Phule Rajini (Rs. 1,46,000/-ha, 3.2) while the local check registered the least net profit of Rs. 1,11,000/-ha and $\mathrm{B}: \mathrm{C}$ ratio of 2.5 . Through this assessment it was found that farmers were very much convinced with the performance of tuberose variety Prajwal, which obtain higher income, higher yield when compared with Phule Rajini and local check.

\section{References}

Bindiya C Naik, Kamble, B. S., Shantappa Tirakannanavar and Savita Parit. 2018. Evaluation of Different Genotypes of Tuberose (Polianthes tuberosa L.) for Growth, Flowering and Yield Characters.

Int.J.Curr.Microbiol.App.Sci.7(07): 4135-4141.

Benschop, M., De Hertogh, A., Le Nard M (1993). The physiology of flower bulbs (Edn) Elsevier, Amsterdam, The Netherlands 589-601

Gudi, G. (2006) Evaluation of tuberose varieties. Thesis submitted to University of Agricultural Sciences, Dharwad, and Karnataka.

Kamble, BS., Reddy BS., Patil RT., Kulkarni BS. 2004. Performance of gladiolus (Gladiolus hybridus Hort.) cultivars for flowering and flower quality. $J$ Ornamental Hort.7: 51-60.

Panse V G and Sukhatme. P V (1985). Statistical Methods for Agricultural Workers. Second Edition. Indian Council of Agricultural Research, New Delhi: 356.

Pathak, S., Choudhuri, MA and Chatterjee, SK (1980). Indian Journal of Plant Physiology, 23: 47- 54.

Prashanta, M., Punetha, P., Rana, DK. 2016.Evaluation of tuberose genotypes for vegetative, floral and bulb yielding attributes under the valley conditions of garhwal Himalayas. Int J Agri. Sci. 8(62):3522- 3524. 
Ramachandrudu, K., Thangam, M. 2009. Performance of tuberose (Polianthes tuberosa L.) cultivars in Goa. J Horti. Sci. 4(1):76-77.

Sadhu, MK, Bose, TK. 1973. Tuberose for most artistic garlands. Indian Hort. 18: 17-20.

Urfi Fatmi and Devi Singh. 2020. Lower quality, yield and bulb production of different varieties of tuberose as affected by different planting time and geometry under Prayagraj agro-climatic conditions. Journal of Pharmacognosy and Phytochemistry.9(2): 74-77.

Vijayalaxmi, M., Manohar Rao A., Padmavatamma AS. and Siva Shanker, A. 2010. Evaluation and variability studies in tuberose (Polianthes tuberosa L.) single cultivars. $J$ Ornamental Hort.13: 251- 256.

Yadav, L P., Bose, TK., and Maity, RG. 1985. Response of tuberose (Polianthes tuberosa L.) to nitrogen and phosphorus fertilization. Prog Hort. 17(2):83-86.

\section{How to cite this article:}

Sivakumar, V., K. Kumanan, A. Kamaraj, R. Balakumbahan and Alex Albert, V. 2020. Assessment of Tuberose (Polianthes tuberosa L.) Varieties for Growth and Flower Yield. Int.J.Curr.Microbiol.App.Sci. 9(08): 1082-1086. doi: https://doi.org/10.20546/ijcmas.2020.908.118 